\title{
CROWN AREA AND TRUNK DIAMETER RELATIONSHIP FOR TREE SPECIES AT A MIXED-ARAUCARIA NATURAL FOREST IN THE MID-SOUTHERN PARANA STATE, BRAZIL
}

\author{
Carlos Roberto Sanquetta ${ }^{1}$, Ana Paula Dalla Corte ${ }^{2}$, Aline Daniele Jacon ${ }^{3}$ \\ ${ }^{1}$ Eng. Florestal, Dr., Depto. de Ciências Florestais, UFPR, Curitiba, PR, Brasil - carlos_sanquetta@ @otmail.com \\ ${ }^{2}$ Eng ${ }^{\mathrm{a}}$ Florestal, Dr ${ }^{\mathrm{a}}$., Curitiba, PR, Brasil - anapaulacorte@gmail.com \\ ${ }^{3}$ Acadêmica de Engenharia Florestal, UFPR, Curitiba, PR, Brasil - alinejacon@ufpr.br
}

Recebido para publicação: 01/04/2010 - Aceito para publicação: 09/08/2010

\begin{abstract}
This paper analyzed the relationship between crown area and diameter at breast height of tree species in a Mixed-Araucaria Forest in mid-southern Parana State, Brazil. The data come from 1 hectare plot where all trees were mapped and had their crown projection drawn in the field and transferred to computer to a SIG environment to relate to DBH. In this paper, 634 individuals $>10 \mathrm{~cm}$ DBH were used for the analysis. Trees were separated in 5 groups: General (all species), Araucaria, Imbuia, Canelas and Others. Outliers from each were properly eliminated from the correlation analysis and regression model testing. Imbuia and Araucaria were those that showed the strongest correlations. Among the models tested, the best fitting was provided by potential function $\left(\ln A C=\beta_{0}+\beta_{1}(\ln D A P)\right)$, with the lowest standard errors of estimate and most homogeneous graphical residual distribution. It was concluded that the relationship between crown area and trunk diameter is stronger in some cases (Araucaria and Imbuia) than when a mix of species is taken into account (Canelas, Others and all species due to the different architecture of the crowns). It is possible to estimate accurately the tree crown area from its diameter when the relationship is strong.

Keywords: Araucaria; crown diameter; crown projection; modeling; regression.
\end{abstract}

\section{Resumo}

Relação de área de copa e diâmetro do fuste para espécies arbóreas da Floresta Ombrófila Mista no centro-sul do Paraná. Avaliou-se a relação entre a área de copa e o diâmetro à altura do peito de árvores de um fragmento de Floresta Ombrófila Mista no estado do Paraná. Os dados são de 1 hectare, onde foram locadas as projeções das copas das árvores, tratadas posteriormente em ambiente SIG para cálculo de área e relação com DAP. Foram utilizados 634 indivíduos $>10 \mathrm{~cm}$ de DAP. As árvores foram divididas em 5 grupos: Geral, Araucária, Imbuia, Canelas e Outras. Foram encontrados outliers, que foram eliminados da análise de correlação e da modelagem. A correlação entre área de copa e diâmetro do fuste foi de 0,75 para o conjunto total. Os grupos Imbuia e Araucária apresentaram as correlações mais fortes. Dos modelos testados, o que melhor se comportou em termos de ajuste foi o potencial $\left(\ln A C=\beta_{0}+\beta_{1}(\ln D A P)\right)$, com menores erros padrões da estimativa e distribuições gráficas de resíduos. Concluiu-se que a relação área de copa e diâmetro do fuste é mais forte em alguns casos (Araucária e Imbuia) e moderada a fraca quando avaliadas espécies com diferentes arquiteturas de copa (Canelas, Outras espécies e conjunto Geral). Nos casos de maior relação, existe a possibilidade de estimar a área de copa em função do diâmetro do tronco.

Palavras-chave: Araucária; diâmetro de copa; projeção de copa; modelagem; regressão.

\section{INTRODUCTION}

All the ecological processes that take place in forest ecosystems depend, one way or another, on the relationship between the arboreal elements, situated upon the area close to the ground and on the upper portion of the canopy. The upper canopy's mechanism, and therefore the forest's as a whole, is strongly influenced by the compounding trees' leaf surface. Studies on the canopy ecology are still scarce (REYNOLDS, 2009). 
There are several different morphometric measurements of individual trees canopy, as well as the crown canopy formed by the forest upper layer. However, to the extent that it consists of a complex three-dimensional structure, due to the branches and foliage shape, it is considerably difficult to find a simple way of representing these dimensions. The most commonly employed numerical expression in canopy studies is the one relating the tree crown diameter and their diameter at breast height (DBH), given their easy measurement.

Different authors, such as Burger (1939) and Assmann (1961) pioneered the studies about shapes, dimensions and the morphometric relationships of the tree crows. Still, very few studies focused on finding the relationship between morphometric variables, such as individual crown area, of difficult measurement, with one that can be measured with ease, such as the DBH. Among recent studies carried out in Brazil are the ones published by Corte et al. (2007) on the Mixed Ombrophylous Forest and Tonini and Arco-Verde (2005) on the Amazon Forest.

Eventhough Schneider (1993) states that several studies show a significant correlation between these dimensions, the majority of its counterparts assume that the crown area can be calculated from two diameters with the ellipse formula, which can reflect in expressive errors on the quantification of the crown surface of the trees that compose the upper layer of the forest.

This article aims to illustrate the relationship between the canopy area and the DBH for species' groups within a Mixed Ombrophylous Forest fragment. Thus, the canopy area's calculation is based upon a visual projection and digitalization in CAD (Computer Aided Design). Based on pairs of values of canopy area and $\mathrm{DBH}$, the data was subjected to a correlation analysis and the development of linear regression models in order to express the canopy area in function of the $\mathrm{DBH}$, aiming to facilitate the canopy area estimate, whose determination is inevitably difficult.

\section{MATERIALS AND METHODS}

\section{Area of study}

The present study was carried out at the Federal University of Paraná (Universidade Federal do Paraná - UFPR) experimental station, located in São João do Triunfo, in the southern portion of the state of Paraná, approximately 125 kilometers from Curitiba (Figure 1).

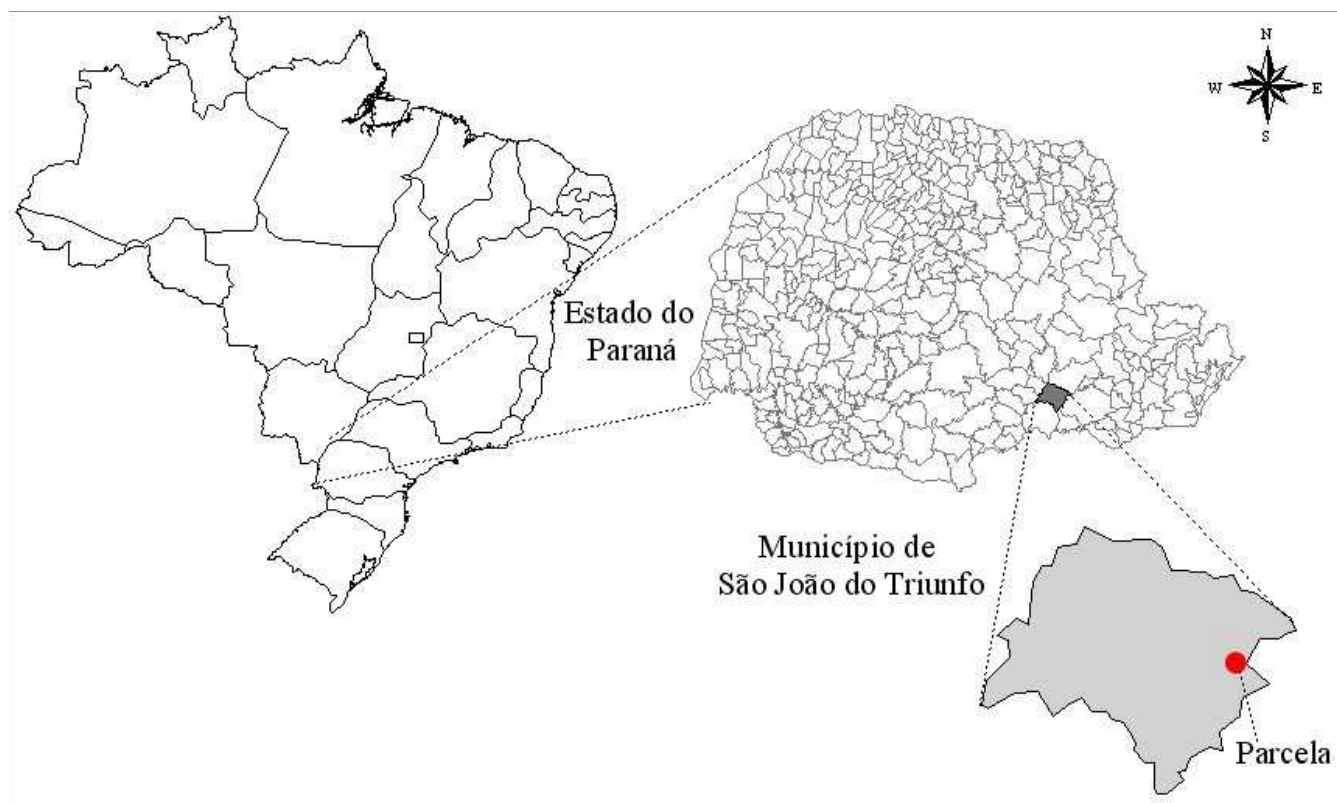

Figure 1. Study site at São João do Triunfo, Parana State, Brazil.

Figura 1. Localização da área de estudo em São João do Triunfo, PR. 
Four permanent plots were established within the 32 hectare area, given that three of them had an area of one hectare $(100 \mathrm{~m} \times 100 \mathrm{~m})$ and one of them consisted of half hectare $(50 \mathrm{~m} \times 100 \mathrm{~m})$, each one divided in subplots of $10 \mathrm{~m} \times 10 \mathrm{~m}$, in order to facilitate the data collection. Monitoring of all the plots is carried out every year, when all the surveyed trees that reach a minimum DBH of 10 centimeters have their diameters remeasured, along with their ingress and mortality records. In this study, only one plot (called the Imbuia Plot) was used, measuring 1 hectare.

The local vegetation consists of a fragment of the Mixed Ombrophylous Forest, according to Velloso et al. (1991), quoted by Pizatto (1999). The forest's soils were classified as ALISOILS, with a small portion of CAMBISOILS. According to the Koppen classification, the weather fits into the $\mathrm{Cfb}$ category - humid temperate weather, with an average temperature inferior to $22^{\circ} \mathrm{C}$ during the hottest month, without a dry season, with cool summers and more than five nightly frosts throughout the year (PIZATTO, 1999).

\section{Methodology}

In this study were used the DBH of 634 trees, as well as their respective canopy projections, carefully drawn in graph paper and transferred to the AutoCAD ${ }^{\circledR}$ software through a scanner, in which the spatial localization of each tree, from the initial coordinate (0.0) and adjusted to an adequate scale. The totality of canopies and their correspondent trunks were outlined one by one over the original image, as shown in figure 2 .

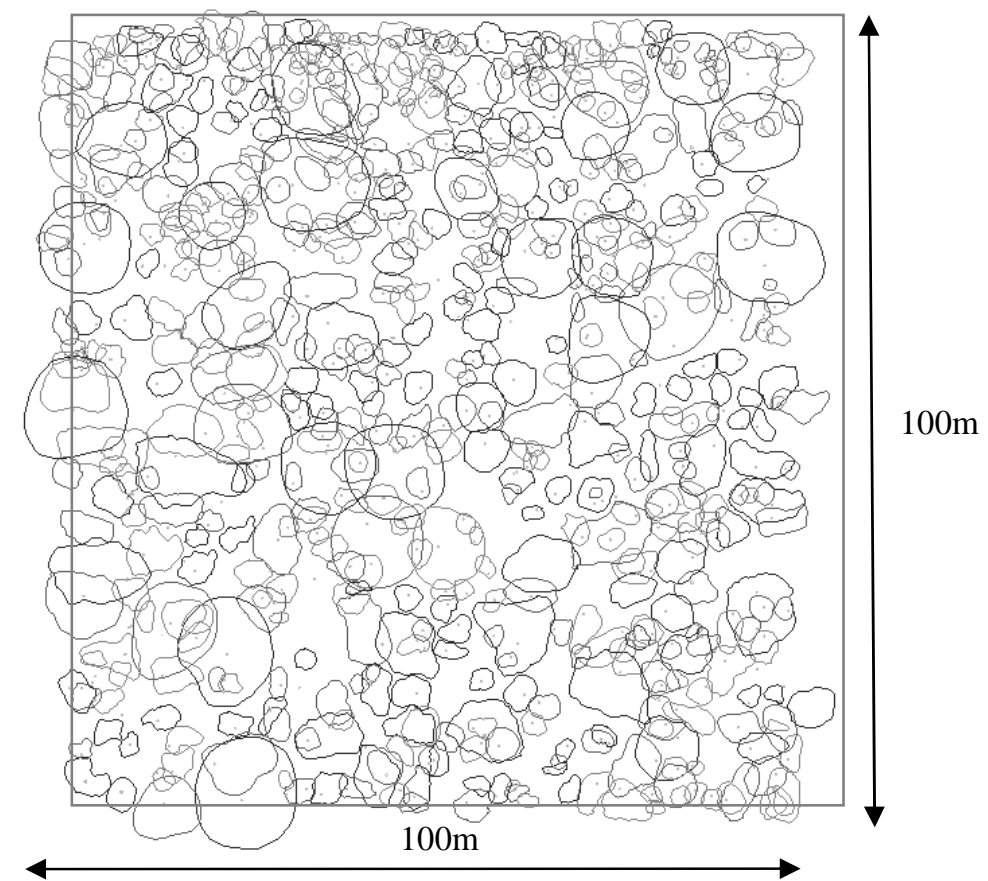

Figure 2. Crown projections of the trees used in this study.

Figura 2. Projeções de copa das árvores empregadas neste trabalho.

After the data collection, five species groups were established for future correlation analysis and equation adjustment. The groups were: General (with 634 individuals), Araucaria (with 47 individuals belonging to the species Araucaria angustifolia (Bert) Kuntze), Imbuia (with 22 individuals of the species Ocotea porosa Ness \& Mart), Canelas (with 77 individuals of Nectandra grandiflora Ness \& Mart and Ocotea puberula (Rich.) Nees) and Others (with 488 individuals of other species, according to Pizatto (1999).

The ARCGIS 9.2® software was employed with the purpose of relating the canopy projections to their correspondent DBH and species, as well as to calculate the area of each individual canopy. The 
canopy diameter was laid aside in favor of the canopy area due to the more than common irregularity on the shape of its respective projections on the ground.

Based on this data, an analysis of the simple correlation coefficient $(r)$ between the interest variables was carried out. According to Silva (1982), $r$ represents the degree of association between two interest variables.

Excluding from the database the so called outlying individuals, due to their interference on the data correlation, the groups ended up with the following numbers of individuals: General with 631, Araucaria with 47, Imbuia with 20, Canelas with 75 and Others with 488.

\section{Data analysis and correlation}

Before starting the equations adjustment, each group had its outliers analyzed. According to Draper and Smith (1981), an outlier is, in absolute values, a point whose behavior doesn't follow the pattern, located far from the average by three, four or more standard deviations. This criterion has been adopted in the present study with the purpose of defining the outlier.

Excluding from the database the so called outlying individuals, due to their interference on the data correlation, the groups ended up with the following numbers of individuals: General with 631, Araucaria with 47, Imbuia with 20, Canelas with 75 and Others with 488.

\section{Equations Adjustment}

In order to express the relationship between the canopy area and the $\mathrm{DBH}$, three previously adjusted mathematical models for adjustment were selected for each species group, found in Schneider (1993), in which:

$$
\begin{aligned}
& \mathrm{AC}=\beta_{0}+\beta_{1}(\mathrm{DAP}) \\
& \ln \mathrm{AC}=\beta_{0}+\beta_{1}(\mathrm{DAP}) \\
& \ln \mathrm{AC}=\beta_{0}+\beta_{1}(\ln \mathrm{DAP}) \\
& \mathrm{AC}=\beta_{0}+\beta_{1}(\mathrm{DAP})^{2} \\
& \mathrm{AC}=\beta_{0}+\beta_{1}(\mathrm{DAP})+\beta_{2}\left(\mathrm{DAP}^{2}\right)
\end{aligned}
$$

Where: $\mathrm{CA}=$ canopy area $\left(\mathrm{m}^{2}\right)$

$\mathrm{DAP}=\mathrm{DBH}=$ diameter breast height $(\mathrm{cm})$

After the removal of the outliers, each of the five equations for each group were adjusted through linear regression using a Microsoft Excel® spreadsheet, aiming to evaluate their performance and select the one with the best statistical behavior.

For the evaluation of the equation adjustment degree and selection of the one with the best performance, the following criteria were employed: corrected determination coefficient $\left(\mathrm{R}^{2}\right)$, which indicates how much percent of the occurred variations are explained in the equation (SILVA, 1982); the estimated standard error in percentage (Sxy\%), a variability measure of the conditional distribution of $\mathrm{Y}$ (canopy area) for fixed values of $\mathrm{X}(\mathrm{DBH})$ and the residual graphic analysis, which indicates the presence or not of tendencies on the estimates, using the adjusted equations. The best equations are the ones that present the highest $\mathrm{R}^{2}$, the lowest $\mathrm{Sxy} \%$ and the least ample and most balanced residual distribution along the adjustment line.

\section{RESULTS AND DISCUSSIONS}

\section{Data analysis and its correlation}

Table 1 enables an overall view of the data amplitude, analyzing each species group separately. It is clear that there is a wider variation on the canopy area than on the trees DBH. The variation coefficients were always higher for the canopy area than for the DBH. The smallest variations on the canopy area occurred for the Araucaria and also for the bigger ones in the General group. 
Table 1. Mean, maximum and minimum values and coefficient of variation (CV\%) of the variable analyzed for each species group.

Tabela 1. Valores médios, máximos, mínimos e coeficiente de variação (CV\%) das variáveis analisadas, em cada grupo de espécies.

\begin{tabular}{lcccccccc}
\hline \multirow{2}{*}{ Group } & \multicolumn{3}{c}{ Crown area $\left(\mathbf{m}^{2}\right)$} \\
\cline { 2 - 9 } & Maximum & Mean & Minimum & CV \% & Maximum & Mean & Minimum & CV \% \\
\hline General (634) & 175,48 & 17,31 & 0,41 & 143,82 & 162,34 & 24,14 & 10,03 & 80,47 \\
Araucaria (47) & 175,48 & 71,18 & 2,70 & 75,40 & 107,27 & 53,93 & 13,69 & 44,86 \\
Imbuia (22) & 93,37 & 24,58 & 2,01 & 109,23 & 162,34 & 46,21 & 10,35 & 97,35 \\
Canelas (77) & 106,79 & 17,79 & 2,91 & 95,34 & 140,69 & 34,15 & 10,35 & 60,38 \\
Outras (488) & 81,68 & 11,72 & 0,41 & 102,27 & 110,45 & 18,70 & 10,03 & 60,63 \\
\hline
\end{tabular}

The figure 3 shows the relation between DBH and canopy areas for the five groups. A direct relationship between both variables could always be verified (positive), which means that the bigger the canopy areas, the bigger the DBHs. There is a significant variability on the data, as shown on figure 3, despite the fact that the aggregation of species reduces its dispersion, making the relationship stronger.

The correlation analysis has shown significant differences referring to the degree of association between the trees' diameter and their canopy area (Figure 3). For the Araucaria, the correlation was strong, showing a more significant regularity between its canopy and its trunk.

According to Nutto (2001), there is a very close relationship between the canopy's width and the DBH for the Araucaria tree, which may be used for the development of new decision tools, applicable to individual trees on Araucaria management in multi-aged and heterogeneous forests or even for the production of high quality wood with pre-selected trees. The relationship between the Araucaria canopy width and the growth in diameter was also tackled by Longhi (1980), Seitz (1986) and Wachtel (1990), evidencing a close association.

The broad-leaved species showed a lower correlation, ranging from 0.57 for the Canelas to 0.77 for the other species. Taking all the species into account altogether, the correlation coefficient was 0.75 . Longhi (1980), who studied separately the Araucaria and the broad-leaved species within the forest, found a straight line trend between the canopy diameter and the DBH on the first case and a parabolic relationship on the second. That suggests important architectural differences in these groups and, very likely, with consequences in their development strategies. A straight line relationship between DBH and canopy area was identified for the Araucaria, although for the broad-leaved the slight curve trend harmonizes with the parabolic proposition found by Longhi (1980).

According to Schneider (1993), several studies show a clear correlation between the DBH and the canopy diameter. The site quality has a direct influence on this correlation: the better the site, the lower is the correlation. That is valid not only for a single species but also for species with similar morphometric characteristics. Wadsworth (2000) also says that the canopy size influences its productivity, and that the trees located on the upper layer of the forest have not very dense horizontal canopies, while the ones on the lower layer have more vertical and deep canopies. Dawkins (1959), quoted by Wadsworth (2000), adds that for the shade intolerant species, the relationship between canopy diameter and DBH is not reduced as the species reaches maturity, as oppose to the shade tolerant species.

According to Durlo et al. (2001), researching the inter-dimensional relationships of single trees is important, because it allows a prediction of the space that is demanded throughout their growth, considering the competition it they find themselves in, besides enabling inferences concerning stability, vitality and productivity of each isolated individual.

Most studies in this field relate the DBH with the canopy diameter. Nevertheless, the canopy irregularity is a complicating factor concerning its area calculus from one or two possible diameters. In this present work, a different strategy was chosen, rather than the canopy diameter measurements and area calculi with the ellipse formula. The most reasonable solution was visually projecting the canopy and drawing it with the computer program $\mathrm{CAD}$, which was considered the most appropriate for picturing the irregularities on the canopy shape, despite a certain amount of subjectivity involved in such evaluation.

In the groups of species where the presence of outliers in the relationship between DBH $\mathrm{x}$ canopy area could be noticed, these points of the analysis were eliminated due to the fact that these were tress with abnormal trunk and canopy conformation. The eliminated points were those located beyond the limit of $99 \%$ of probability within the normal curve. Three individuals were withdrawn from the General group, in comparison to two both in the Imbuia and Canela group. This simple elimination enabled a rise on the correlation coefficient, as shown in table 3. 

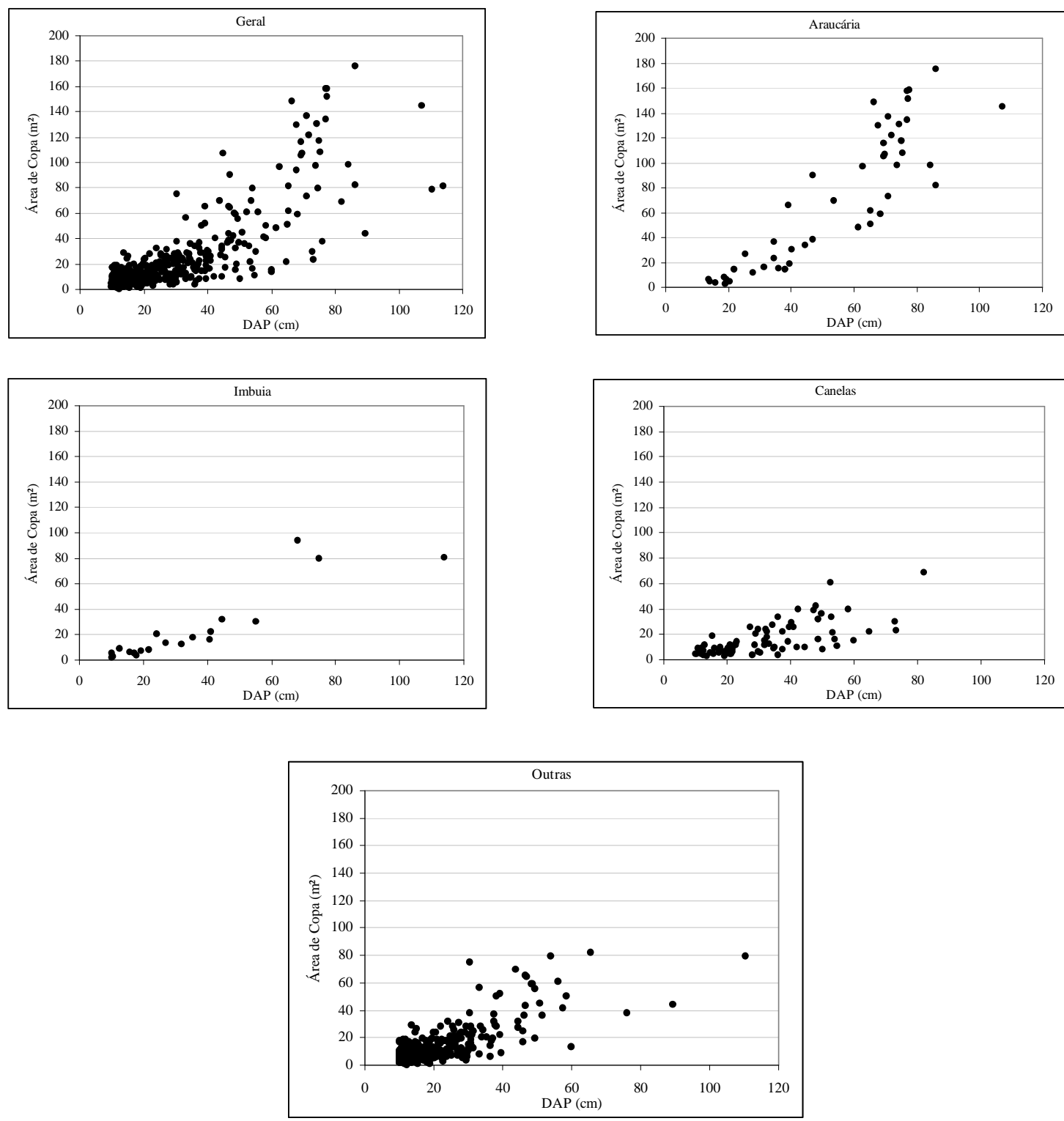

Figure 3. Relationship between DBH and crown projection area by species group. Figura 3. Relação entre DAP e área de copa das árvores avaliadas nos grupos.

Table 3. Simple coefficient of correlation of DBH and crown area, either with or without outliers.

Tabela 3. Coeficiente de correlação simples entre DAP e área de copa, com e sem outliers.

\begin{tabular}{lcc}
\hline Group & r - with outliers & r - without outliers \\
\hline General & 0,75 & 0,81 \\
Araucaria & 0,88 & 0,88 \\
Imbuia & 0,62 & 0,90 \\
Canelas & 0,57 & 0,68 \\
Outras & 0,77 & 0,77 \\
\hline
\end{tabular}




\section{Equations adjustment}

The adjusted equations for the different groups are shown in table 4 , with their respective $\mathrm{R}^{2} \mathrm{e}$ Sxy\%. For the Araucaria, Imbuia and Canela groups, the model with the best results was the number 1 (straight line), with the lowest Syx\% and highest $\mathrm{R}^{2}$. AS for the General group, the model number 5 (parabolic) has outperformed all the others and for the Others group, the models 1 and 5 showed the same behavior through the adjustment indicators analysis (Figure 4).

Table 4. Equations for estimating crown area as a function of DBH per species group.

Tabela 4. Equações para estimar área de copa em função do DAP, por grupo de espécies.

\begin{tabular}{|c|c|c|c|c|c|c|}
\hline Group & Model & $\beta_{0}$ & $\beta_{1}$ & $\beta_{2}$ & $\mathbf{R}^{2}$ & Syx \% \\
\hline \multirow{5}{*}{ General } & 1 & $-10,3945$ & 1,1733 & - & 0,23 & $147,5 \%$ \\
\hline & 2 & $-76,6498$ & 31,5929 & - & 0,52 & $100,4 \%$ \\
\hline & 3 & $-1,4669$ & 1,2744 & - & 0,20 & $146,98 \%$ \\
\hline & 4 & 5,7620 & 0,0135 & - & 0,66 & $84,4 \%$ \\
\hline & 5 & $-2,7842$ & 0,6010 & 0,0069 & 0,68 & $82,5 \%$ \\
\hline \multirow{5}{*}{ Araucaria } & 1 & $-34,5152$ & 1,9599 & - & 0,78 & $47,1 \%$ \\
\hline & 2 & $-242,1779$ & 81,2483 & - & 0,71 & $53,3 \%$ \\
\hline & 3 & $-4,1028$ & 2,0405 & - & 0,72 & $52,5 \%$ \\
\hline & 4 & 8,8410 & 0,0179 & - & 0,74 & $50,9 \%$ \\
\hline & 5 & $-35,6111$ & 2,0132 & $-0,0005$ & 0,77 & $47,7 \%$ \\
\hline \multirow{5}{*}{ Imbuia } & 1 & $-9,4082$ & 0,9433 & - & 0,81 & $53,4 \%$ \\
\hline & 2 & $-86,3793$ & 33,1665 & - & 0,68 & $67,5 \%$ \\
\hline & 3 & $-2,2450$ & 1,4582 & - & 0,78 & $57,9 \%$ \\
\hline & 4 & 8,9159 & 0,0077 & - & 0,69 & $66,8 \%$ \\
\hline & 5 & $-13,9057$ & 1,1997 & $-0,0023$ & 0,79 & $54,1 \%$ \\
\hline \multirow{5}{*}{ Canelas } & 1 & $-1,4117$ & 0,5417 & - & 0,47 & $59,7 \%$ \\
\hline & 2 & $-37,8442$ & 16,1430 & - & 0,41 & $67,8 \%$ \\
\hline & 3 & $-0,8834$ & 1,0082 & - & 0,41 & $62,5 \%$ \\
\hline & 4 & 7,4107 & 0,0066 & - & 0,44 & $61,0 \%$ \\
\hline & 5 & 0,3828 & 0,4254 & 0,0015 & 0,46 & $60,4 \%$ \\
\hline \multirow{5}{*}{ Outras } & 1 & $-3,4293$ & 0,8101 & - & 0,59 & $65,8 \%$ \\
\hline & 2 & $-42,4400$ & 19,2629 & - & 0,51 & $71,9 \%$ \\
\hline & 3 & $-1,1515$ & 1,1697 & - & 0,54 & $70,0 \%$ \\
\hline & 4 & 7,1692 & 0,0095 & - & 0,49 & $73,3 \%$ \\
\hline & 5 & $-4,2140$ & 0,8753 & $-0,0009$ & 0,59 & $65,8 \%$ \\
\hline
\end{tabular}

It is evident that the straight line model that relates DBH directly with the canopy area, despite its simple structure, as soundly shown in the work of Dawkins (1963), quoted by Longhi (1980), managed to represent this relationship in a satisfying way. This better performance can be explained by the study about Araucaria angustifolia carried out by Volkart (1969), who verified a rectilinear tendency with a positive origin between the canopy diameter and the trunk diameter, obtaining a correlation coefficient of 0.96. Thus, Brunig and Heuveldop (1976) found in tropical forests a rather meaningful linear relationship between canopy diameter and the trunk.

According to Longhi (1980), for the Araucaria angustifolia, the correlation coefficient was 0.92 for both canopy and trunk diameters, resulting in a straight relationship between both. Oliveira (1982), in his study on the Araucaria angustifolia, pointed out to a simple correlation between DBH and canopy diameter of 0.85 .

The parabolic relationship found by Longhi (1980) for broad-leaved species resulted in a correlation of 0.82. The same author states that, eventhough for the Araucaria angustifolia, the bigger the trunk diameter, the bigger the canopy diameter, this tendency can't be understood as a rule for the broad- 
leaved, because up to a certain age, this relationship remains and, later on, despite the increase on the tree's diameter, the canopy diameter starts do decrease.
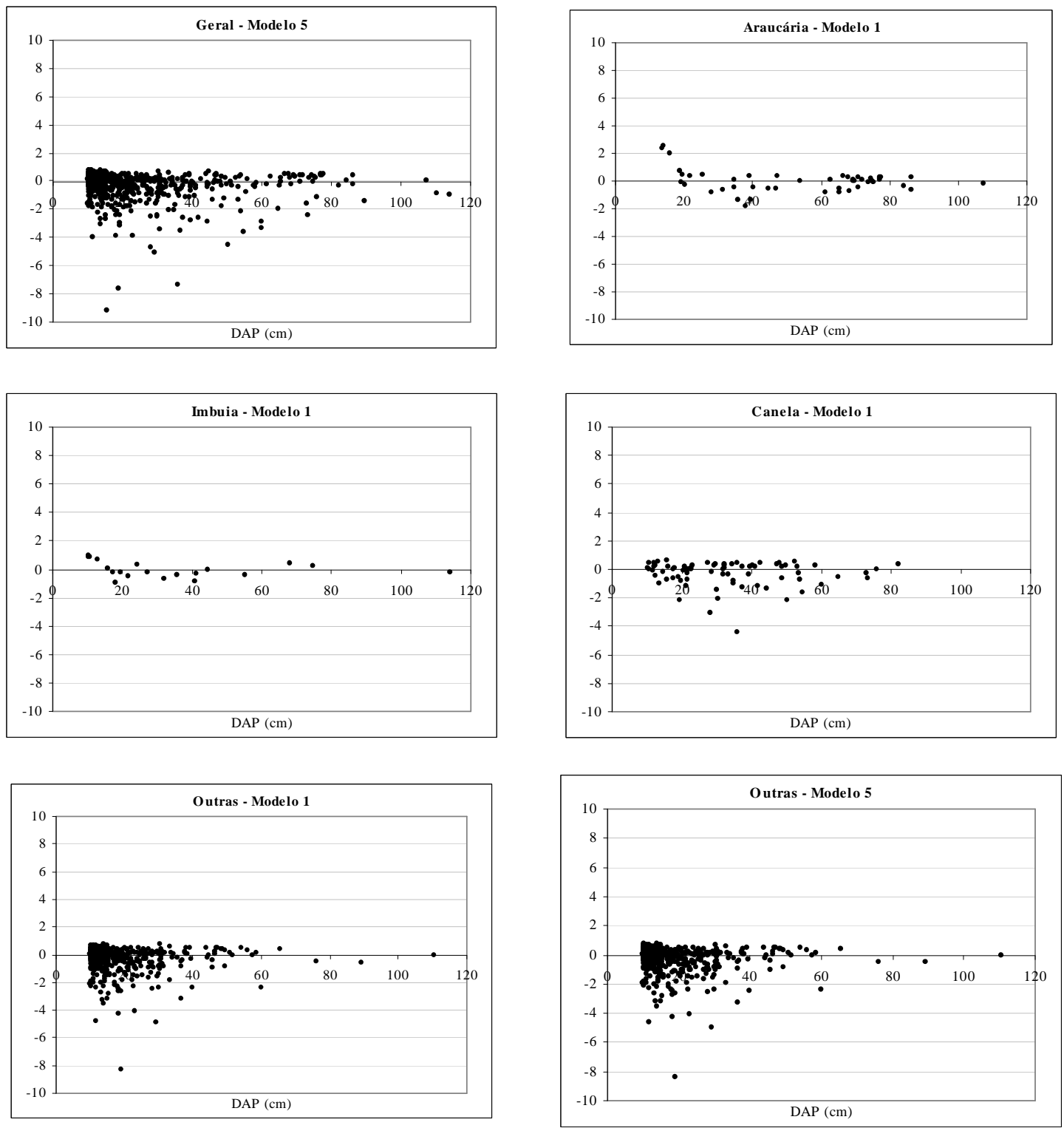

Figure 4. Graphical residue analysis for the best fitting models.

Figura 4. Análise gráfica da distribuição dos resíduos para os melhores modelos ajustados.

\section{CONCLUSIONS}

The conclusions of this work were the following:

- There is a correlation between canopy area and DBH, although it's not always significative. For individual species with similar canopy architecture, like the Araucaria, the relationship is quite stable, as endorsed by the literature.

- On the cases in which the relationship in epigraph is stronger, there is the possibility of accurately estimating the canopy area in relation to the trunk diameter. 
- The potential model has shown to be the one with best behavior when it comes to expressing the relationship between the canopy and the $\mathrm{DBH}$, in comparison to the other ones tested.

- Outliers on the original data must be identified and excluded from de modeling.

- In spite of the subjectivity on the canopies' outlining, a conclusion has been reached that this is the most adequate way to picture the canopy area, instead of using the ellipsis formula.

- The canopy area is an important biometric expression for ecological and forest production studies. Estimating them accurately from easily obtainable measurements is, whenever possible, highly recommended.

\section{REFERENCES}

ASSMAN, E. Waldertargskunde. Müchen; Bayr: Landw, Verlag, 1961. 490 p.

BRUNIG, E. F.; HEUVELDOP, J. Structure and functions in natural and man-made forests in the humid tropics. In: Iufro World Congress. 16. Norway, 1976. 500-511 p.

BURGER, H. Baumkrone und Zuwachs in zwei hiebsreifen Fichtenbestanden. Mitt. Schweiz. Anst. f. forstl. Vers. Wesen, v. 21, p. 147-176, 1939.

CORTE, A. P. D.; CANALEZ, G. G.; SANQUETTA, C. R. Caracterização da estrutura vertical e do dossel de um fragmento de Floresta Ombrófila Mista. Irati. Ambiência, v. 3, p. 13-25, 2007.

DAWKINS, H. C. Crown diameters: their relationship to bole diameter in tropical trees. Commonw. Forest Review, v. 42, p. 318-333, 1963.

DRAPER, N. R.; SMITH, H. Applied regression analysis. 2. ed. New York: John Wiley, 1981. 709 p.

DURLO, M. A. Relações morfométricas para Cabralea canjerana (Vell.) Mart. Ciência Florestal, v. 11, p. 141-149, 2001.

LONGHI, S. J. A estrutura de uma floresta natural de Araucaria angustifolia (Bert.) O. Ktze. no Sul do Brasil. 198 p. Dissertação (Mestrado em Ciências Florestais) - Universidade Federal do Paraná, Curitiba, 1980.

NUTTO, L. Manejo do crescimento diamétrico de Araucaria angustifolia (Bert). O. Ktze. baseado na árvore individual. Ciência Florestal, v. 11, p. 9-25, 2001.

OLIVEIRA, Y. M. M. de. Correlações entre parâmetros dendrométricos em Araucaria angustifolia utilizando fotografias aéreas. 133 p. Dissertação (Mestrado) - Universidade Federal do Paraná, Curitiba, 1982.

PIZATTO, W. Avaliação biométrica da estrutura e da dinâmica de uma Floresta Ombrófila Mista em São João do Triunfo, PR: 1995 a 1998. 172 f. Dissertação (Mestrado) - Universidade Federal do Paraná, Curitiba, 1999.

REYNOLDS, B. C. Current understanding of forest canopy ecology. In: $94^{\text {th }}$ ESA ANNUAL MEETING. Albuquerque, New Mexico. 2009. <http://esameetings.allenpress.com/2009/Paper16182.html>. Acesso em 26/03/2009.

SCHNEIDER, P. R. Introdução ao manejo florestal. Santa Maria: Ed. UFSM, 1993. 348 p.

SEITZ, R. Erste Hinweise für die waldbauliche Behandlung von Araukarienwäldern. Annales des Sciences Forestieres, 43. p. 327-338, 1986.

SILVA, J. A. Funções de forma dos troncos do Pinus taeda, Picea excelsa, Abies alba e Pinus silvestris. In: Seminário sobre atualidades e perspectivas florestais: o uso de funções de forma do tronco em estudo de volumetria de espécies florestais. 1981, Curitiba. Anais... Curitiba, EMBRAPA-URPFCS, 1982. 108 p. 29-43.

TONINI, H.; ARCO-VERDE, M. F. Morfologia da copa para avaliar o espaço vital de quatro espécies nativas da Amazônia. Pesquisa Agropecuária Brasileira, v. 40, p. 633-638, 2005. 
VOLKART, C. M. Determinación de la relación diámetro de copa: diámetro del tronco en Araucaria angustifolia y Pinus elliottii en la Provincia de Misiones. In: Congresso Forestal Argentino. 1. Buenos Aires. 1969. 231-237 p.

WACHTEL, G. Untersuchungen zu Struktur und Dynamik eines Araukarien-Naturwaldes in Südbrasilien. Freiburg: UF, 1990. 180 p. Dissertação (Doutorado) - Universität Freiburg, 1990.

WADSWORTH, F. H. Producción forestal para América tropical. Washington: USDA, 2000. 563 p. 